\title{
ABUNDANCE AND NEIGHBORHOOD STRUCTURE FOR SPARSE AND COMMON GRASSES IN A MISSOURI PRAIRIE ${ }^{1}$
}

\author{
Deborah Rabinowitz, Barbara K. Bassett, and Gregory E. Renfro \\ Division of Biological Science, University of Michigan, Ann Arbor 48109; Missouri Department of \\ Conservation, 2901 North 10 Mile Road, Jefferson City 65101; and Department of Fisheries, \\ Forestry and Wildlife, University of Missouri, Columbia 65211
}

\begin{abstract}
A B S T R A C T
Biomass abundance and distance from a random point to the nearest flowering culm were measured during two seasons for eight species of native perennial grasses on a continuum from locally rare to common in a Missouri tall prairie. Mean abundance from the most common to the most rare ranges over three orders of magnitude (nine octaves) from 73 to $.25 \mathrm{~g} / \mathrm{m}^{2}$. The means of the distance to a culm range over two orders of magnitude (four octaves) from $0.3 \mathrm{~m}$ to $5.0 \mathrm{~m}$. The logarithm of distance to a culm is linearly correlated with the logarithm of abundance. Distance to an inflorescence is greater for sparse species than for common species.
\end{abstract}

WITHIN a community, the abundance exhibited by the component species varies enormously. Some species are very common, and many others are locally rare. The distribution of abundance among species generally is log-normal in high diversity non-successional sites (Preston, 1948, 1962a,b; Whittaker, 1965, 1972, 1975; Bazzaz, 1975). A possible consequence of this spread in abundance is that individuals of a locally rare species may be separated by long distances from conspecifics and potential mates. This study of prairie grasses on an abundance continuum was undertaken to answer several questions. How does the distance to an inflorescence relate to the abundance of a species? Is the distance to an inflorescence of a locally rare species greater than that of a common species? What consequences might a negative correlation of abundance and distance to an inflorescence have on the reproductive characteristics of the species?

MATERIALS AND METHODS-The study site is Tucker Prairie Research Area, in Callaway County, Missouri. The 64.8 ha (160 acre) remnant of tall grass or true prairie (Weaver, 1954) was mowed and grazed until 1957 , but the sod has never been turned. The prairie is burned on an approximately four year rotation. The site, underlain by a claypan, is poorly drained and flat, sloping over a range of $6 \mathrm{~m}$.

\footnotetext{
${ }^{1}$ Received for publication 11 December 1978; revision accepted 3 April 1979.

This research was carried out while the first author was a Visiting Assistant Professor at the University of Missouri. We wish to thank Jody Rapp for assistance in the field and Clair L. Kucera for encouragement. The research was supported by a grant from the National Science Foundation (DEB78-11179)
}

The prairie contains about 240 species of vascular plants, of which $\mathbf{3 8}$ are grasses. Ten of the grass species are weedy aliens which occur predominantly near the boundary fence. Of the remaining 28, 6 are native annuals, and 22 are native perennials. Of the native perennials, eight species were selected to represent a wide range of abundance from dominant to locally very rare. The species are Agrostis hiemalis (Walt.) B.S.P., Andropogon gerardi Vitman, A. scoparius Michx. (=Schizachyrium scoparius [Michx.] Nash), Festuca paradoxa Desv., Setaria geniculata (Lam.) Beauv., Sorghastrum nutans (L.) Nash, Sphenopholis obtusata (Michx.) Scribn., and Sporobolus heterolepis A. Gray. Nomenclature follows that of Kucera (1961).

Within a 16 ha section of the prairie, two series of observations were performed: an assessment of abundance as standing crop and a measurement of distance to flowering culms of each species.

To measure standing crop, we placed 90.10 $\mathrm{m}^{2}$ circular quadrats at random in an area totalling $900 \mathrm{~m}^{2}$, during June, July, and early August 1977. All live higher plants (green material) with bases within the quadrat were clipped at soil level and sorted into one of eleven categories: the eight species under study; other graminoids (mostly Carex spp. and Juncus sp.); forbs (mostly Solidago spp.); and woody plants (mostly Rosa sp.). The plants were oven-dried at $80 \mathrm{C}$ for 24 hours and weighed.

Because the prairie is flat, the dispersion of the species in the area is quite homogeneous. No vertical habitat separation of the species occurs, as would be the case in an area of marked topographic variation, such as that studied by Platt (1975), Werner and Platt (1976), and Platt and Weis (1977). Because some of the species are 


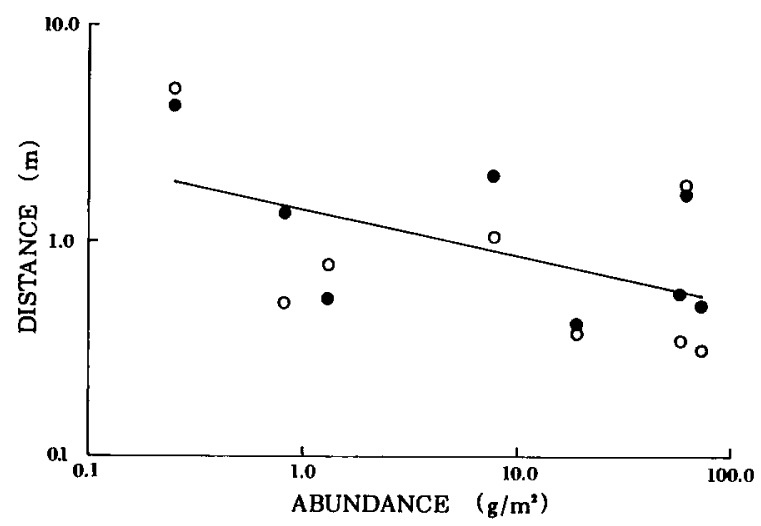

Fig. 1. Mean biomass abundance $\left(\mathrm{g} / \mathrm{m}^{2}\right)$ versus the mean of the distance from a random point to a flowering culm (m) for eight species of prairie grasses in 1977 (solid circles) and 1978 (open circles). See Table 1 for standard errors. $N=90$ for abundance; $\mathrm{N}=25$ for distance to a culm. $\mathrm{r}=-0.521$, $0.05<P<0.01$. $\ln \mathrm{y}=0.33-0.21 \ln \mathrm{x}$.

quite rare, many small quadrats (as opposed to fewer, larger ones) are required to detect their presence. Thus, the sampling scheme is presumed to yield accurate estimates of biomass abundance, and the standard errors of the means are set primarily by quadrat size and frequency.

Distance from a random point to the nearest flowering culm was measured in $0.5 \mathrm{~m}$ classes for each species during two seasons, 1977 and 1978. Twenty-five random points on the prairie were established by drawing pairs of random numbers corresponding to grid points. Mean distance from a random point to a culm is identical to distance from culm to culm only if the spatial distribution of culms is random (Pielou, 1974).

RESUlTs-Biomass abundance and distance from a random point to the nearest culm for the eight grass species are shown in Table 1. Abundance varies over three orders of magnitude from the most abundant to the most rare. In terms of halvings of abundance (Preston, 1962a,b), the range spans nine octaves. Fully censused plant communities contain 14 cover octaves in semidesert (Whittaker, 1965) and 10 cover octaves in 40-year-old forest (Bazzaz, 1975). Assuming that cover and biomass are proportional, the rarest species in the present study is several octaves to the left of the modal octave, and the abundance spectrum is more than half revealed. Mean distance from a random point to a flowering culm ranges over two orders of magnitude or four octaves.

The relationship between abundance and distance to a culm is shown in Fig. 1. The correlation of the logarithm of the means is statistically significant $(\mathrm{r}=-0.521,0.05>P>0.01)$.

Discussion-The distance from a random point to a flowering culm is significantly greater for rare species than for common. For the most common species, Andropogon scoparius, $73 \mathrm{~g} /$ $\mathrm{m}^{2}$, the distance to a culm is $.5 \mathrm{~m}$ in 1977 and $.3 \mathrm{~m}$ in 1978. For the most rare species, Sphenopholis obtusata, $0.25 \mathrm{~g} / \mathrm{m}^{2}$, the distance is 4.2 $\mathrm{m}$ in 1977 and $5.0 \mathrm{~m}$ in 1978 . This result is the first demonstration of a relationship between abundance and neighborhood structure.

The rarest of the species, Sphenopholis obtusata, has a maximum observed distance to a culm of $21.5 \mathrm{~m}$ in 1977 and $30.0 \mathrm{~m}$ in 1978 . These distances are well within those that wind-blown grass pollen is observed to travel (Levin and Kerster, 1974). Thus, the greater distances that pollen must travel to achieve outcrossing in rarer species is not so large as to preclude wind pollination. However, low density of rarer species means that there will be less total pollen in the

TABLE 1. Abundance as standing crop of eight species of prairie grasses in 1977 (dry weight of live material clipped at soil level from $90.10 \mathrm{~m}^{2}$ circular quadrats, mean \pm standard error) and distance from a random point to a flowering culm for 1977 and 1978 (mean \pm standard error, $N=25$ )

\begin{tabular}{lccc}
\hline \hline & $\begin{array}{c}\text { Abundance } \\
\left(\mathrm{g} / \mathrm{m}^{2}\right)\end{array}$ & \multicolumn{1}{c}{ Distance $(\mathrm{m})$} \\
\cline { 2 - 4 } & $73.00 \pm 13.23$ & $\mathbf{1 9 7 7}$ & 1978 \\
\hline Andropogon scoparius & $62.47 \pm 19.79$ & $0.5 \pm 0.1$ & $0.3 \pm 0.0$ \\
Sporobolus heterolepis & $58.39 \pm 9.58$ & $1.7 \pm 0.5$ & $1.8 \pm 0.4$ \\
Andropogon gerardi & $19.31 \pm 7.86$ & $0.6 \pm 0.1$ & $0.4 \pm 0.1$ \\
Sorghastrum nutans & $7.79 \pm 1.17$ & $0.4 \pm 0.1$ & $0.4 \pm 0.1$ \\
Festuca paradoxa & $1.32 \pm 0.36$ & $2.0 \pm 0.3$ & $1.0 \pm 0.2$ \\
Agrostis hiemalis & $0.81 \pm 0.22$ & $1.4 \pm 0.2$ & $0.8 \pm 0.2$ \\
Setaria geniculata & $0.25 \pm 0.15$ & $4.2 \pm 1.0$ & $0.5 \pm 0.1$ \\
Sphenopholis obtusata & $29.30 \pm 2.44$ & & $5.0 \pm 1.4$ \\
Other graminoids & $107.23 \pm 9.57$ & & \\
Forbs & $14.64 \pm 5.08$ & & \\
Woody plants & $374.50 \pm 20.90$ & & \\
Total & & & \\
\hline
\end{tabular}


air currents, and this effect will compound the attenuation of pollen density with distance from source. Thus, rare species may suffer from pollen capture inadequate to insure complete fertilization, and such a predicament may have profound evolutionary impact on breeding system. Trends in breeding system may occur from outcrossing in common species to autogamy or agamospermy in sparse species.

\section{LITERATURE CITED}

BAzzaz, F. A. 1975. Plant species diversity in old-field successional ecosystems in southern Illinois. Ecology 56: $485-488$.

KuCERA, C. L. 1961. The grasses of Missouri. University of Missouri Press, Columbia, Missouri.

Levin, D. A., ANd H. W. Kerster. 1974. Gene flow in seed plants. Evol. Biol. 7: 139-220.

Pielou, E. C. 1974. Population and community ecology: principles and methods. Gordon and Breach, New York.
Platt, W. J. 1975. The colonization and formation of equilibrium plant species associations on badger disturbances in a tall-grass prairie. Ecol. Monogr. 45: 285-305.

-, AND I. M. WEIS. 1977. Resource partitioning and competition within a guild of fugitive prairie plants. Amer. Nat. 111: 479-513.

Preston, F. W. 1948. The commonness and rarity of species. Ecology 29: 254-283.

- 1962a. The cannonical distribution of commonness and rarity: part I. Ecology 43: 410-432.

- 1962b. The cannonical distribution of commonness and rarity: part II. Ecology 43: 410-432.

Weaver, J. E. 1954. North American prairie. Johnsen Publishing Company, Lincoln, Nebraska.

Werner, P. A., AND W. J. Platt. 1976. Ecological relationships of co-occurring goldenrods (Solidago: Compositae). Amer. Nat. 110: 959-971.

WhitTaker, R. H. 1965. Dominance and diversity in land plant communities. Science 147: 250-260.

. 1972. Evolution and measurement of species diversity. Taxon 21: 213-251.

1975. Communities and ecosystems. 2nd ed. Macmillan Company, New York. 